\title{
Chlorotoxin-A Multimodal Imaging Platform for Targeting Glioma Tumors
}

\author{
Gadi Cohen ${ }^{1, *}$, Scott R. Burks ${ }^{1}$ and Joseph A. Frank ${ }^{1,2, *}$ \\ 1 Frank Laboratory, Radiology and Imaging Sciences, Clinical Center, National Institutes of Health, \\ Bethesda, MD 20892, USA; scott.burks@nih.gov \\ 2 National Institute of Biomedical Imaging and Bioengineering, National Institutes of Health, \\ Bethesda, MD 20892, USA \\ * Correspondence: gadi.cohen@nih.gov (G.C.); jfrank@cc.nih.gov (J.A.F.); Tel.: +1-301-435-4635 (J.A.F.)
}

Received: 18 October 2018; Accepted: 23 November 2018; Published: 26 November 2018

check for updates

\begin{abstract}
Chlorotoxin (CTX) is a 36-amino-acid disulfide-containing peptide derived from the venom of the scorpion Leiurus quinquestriatus. CTX alters physiology in numerous ways. It interacts with voltage gated chloride channels, Annexin-2, and matrix metalloproteinase-2 (MMP-2). CTX-based bioconjugates have been widely subjected to phase I/II clinical trials and have shown substantial promise. Many studies have demonstrated that CTX preferentially binds to neuroectodermal tumors, such as glioblastoma, without cross-reactivity to normal brain cells. With its ability to penetrate the blood-brain-barrier (BBB) and its tyrosine residue allows covalent conjugation with functional moieties, CTX is an attractive platform to explore development of diagnostic and therapeutic agents for gliomas. In this review, we outline CTX structure and its molecular targets, summarize molecular variations of CTX developed for glioma imaging, and discuss future trends and perspectives for CTX conjugates as a theranostic agent.
\end{abstract}

Keywords: chlorotoxin; glioblastoma; imaging modalities

Key Contribution: This paper provides an overview of CTX bioconjugates utilized for targeted imaging and therapy of glioma, and discusses future trends and perspectives in developing CTX conjugates for theranostic applications.

\section{Chlorotoxin (CTX) as A Potential Targeting Agent for Glioblastoma}

Glioblastoma multiforme (GBM), represents the most common primary brain malignancy and is defined by its invasiveness and capacity for proliferation [1]. Although imaging techniques continue to advance, prognoses remain poor with a five-year survival rate of 5.5\% [2,3]. Current standard therapies include surgical resection, followed by concurrent radiation with adjuvant chemotherapy [4]. Extensive surgical resection of GBMs is problematic as these tumors are highly invasive and extend into anatomical brain regions that are not amenable to surgery [5]. Preoperative planning now incorporates a variety of imaging modalities, including functional magnetic resonance imaging (MRI) and diffusion tensor imaging, computed tomography (CT), and MRI with direct stimulation during surgery, which have enabled more extensive resection capabilities that lessen the impacts on neurological function or quality of life [6]. Despite these advances, distinguishing normal brain from residual tumor tissues remains difficult [7]. Moreover, determining a patient's glioblastoma subtype by immunohistochemistry remains a diagnostic challenge for the neuropathologist since hematoxylin and eosin staining of GBM can reveal a wide variety of pathologies that resemble other central nervous system lesions [8]. CTX is a 36 amino acids neurotoxin derived from the Israeli yellow scorpion's venom, Leiurus quinquestriatus (Figure 1A). CTX has been purposed as a potential candidate 
for differentiating between molecular profiles and radiologic features of GBM, and could serve as a platform for developing novel noninvasive technique [9]. Molecular targets for CTX include voltage gated chloride channels [10-12], calcium-dependent phospholipid-binding protein Annexin-2 [13], and the inducible extracellular enzyme matrix metalloproteinase (MMP)-2 [12-14]. CTX has come to be an attractive platform for development of intraoperative imaging agents due to several structural advantages including; four disulfide linkages that impart a stable tertiary structure and a tyrosine residue that can be conjugate to a variety of imaging agents (Figure 1B) and its preferential binding to tumor cells (Figure 1C). CTX also binds glioblastoma tumor cells in a grade-related manner and does not cross-react with normal brain $[15,16]$. Given its unique structural and biological properties, CTX has the potential to be used as a targeting agent in a variety of applications used for diagnosing or treating GBM tumors.
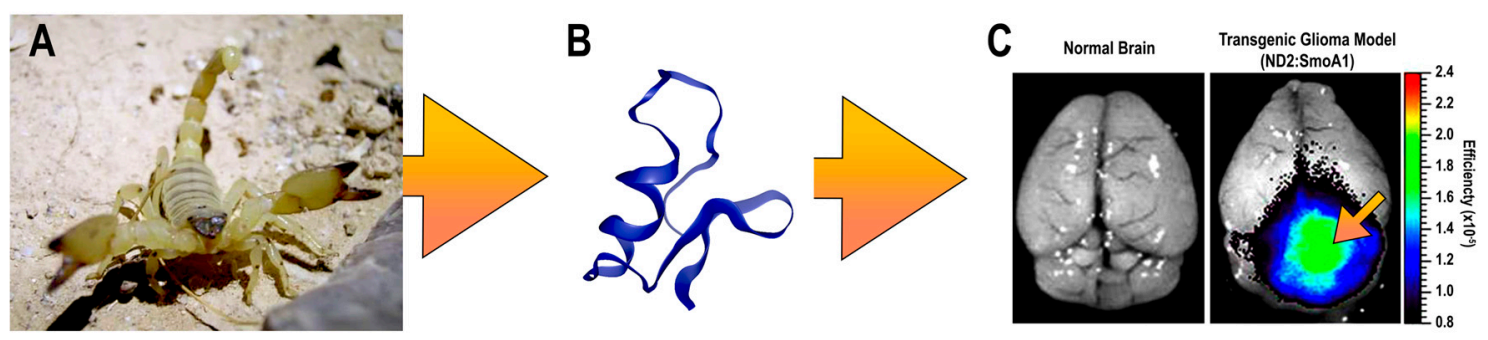

Figure 1. (A) The Israeli scorpion Leiurus quinquestriatu, from which its venom, chlorotoxin (CTX), is derived. (B) Three-dimensional structure of CTX reproduced from 1CHL PDB file [17], 1995, Biochemistry. (C) Visualization of IRDye 800CW-CTX targeting spontaneously develops medulloblastoma tumors in ND2:SmoA1 mice GBM. Left side: normal mouse brain. Right side: transgenic mouse model. Tumor location is marked using an orange arrow. Adapted with permission from Akcan et al. Reproduced from Reference [18], 2011, American Chemical Society.

\section{CTX Structure and Molecular Targets}

CTX is a $4 \mathrm{kD}$ peptide consisting of 36 amino acids [19]. CTX is comprised of three short anti-parallel $\beta$-sheets tightly packed around an $\alpha$-helix [17] and four disulphide linkages which contribute to a compact structure. The three-dimensional structure of CTX has been also determined by NMR spectroscopy (Figure 1B) [17,20]. CTX is named from its pharmacological effect of blocking small-conductance epithelial chloride channels [19]. Moreover, radio-receptor assay results were consistent with the chloride-conducting ion channel $(\mathrm{ClC})$ family [10], and prolonged exposure to CTX stimulates intracellular internalization of these channels [12]. The discovery of specific CTX-sensitive glioma chloride currents in acute slices of human gliomas [21] highlight its potential use in glioma treatment. Even though gliomas present a wide degree of antigenic variability, they almost universally appear to over-express a CTX-sensitive chloride current [11,22]. These channels are absent or in low abundance in healthy tissues or in tumors of non-glial origin [23]. Interestingly, the expression level of these chloride channels appears to be correlated with the histopathological tumor grade despite the role of this channel type in the disease process remaining obscure. Experiments showed that submicromolar concentrations of CTX cannot block volume-regulated, $\mathrm{Ca}^{2+}$ activated and cystic fibrosis transmembrane conductance regulator chloride channels, suggesting CTX cannot be classified as a general chloride channel toxin [24]. Moreover, two binding sites for CTX were identified in vitro using glioma cell lines: a high affinity binding site with a Kd value of 4-9 $\mathrm{nM}$ and a low affinity one with a $\mathrm{Kd}$ in the $0.5-1 \mu \mathrm{M}$ range. These results suggest more than one CTX-sensitive membrane receptor on the glioma cell surface [10] and may imply that the interaction between CTX and its target molecules are described by different binding affinities [14,25]. CTX has also been demonstrated to selectively and specifically act on matrix metalloproteinase (MMP)-2, which is expressed in glioma and other tumors, but is not present in normal brain tissues. It is part of the larger family of metalloproteases that have been associated with the enzymatic degradation of the extracellular matrix (ECM). Increased 
MMP-2 expression is related to the tissue invasion capacity of glioma cells. CTX can decrease the surface expression of MMP-2 and also inhibit its activity, thereby reducing overall invasion ability of glioma cells through compact extracellular spaces in normal brain tissue [14]. Although the molecular mechanisms of CTX in glioma remains elusive, there is a general agreement that CTX binds specifically to a membrane complex of chloride channel-3 (ClC-3) and MMP-2 [26], which may cause endocytosis of ClC-3/MMP-2 and a reduction of glioma invasiveness.

In 2010, Kesavan et al. identified annexin A2 as a novel target molecule for TM-601 in human umbilical vein endothelial cell and multiple human tumor cell lines [27]. Annexin A2 is a calcium-dependent phospholipid binding protein present on the extracellular side of the plasma membrane of various tumor cells and endothelial cell types. It has many roles in cellular functions such as angiogenesis, apoptosis, cell migration, proliferation, invasion and cohesion. However, little is known about the inhibition of glioma invasion in the brain by CTX with regard to its annexin A2 binding capability. TM-601 was found to bind the surfaces of Panc-1 cells depending on the level of annexin A2 expression. [27]. Small interfering ribonucleic acid (siRNA) knockout of annexin A2 results in reduced binding of a technetium-99m-labelled-TM601 in cell lines expressing annexin A2 [28].

\section{Molecular Imaging of Glioblastoma}

Several recent developments in cancer diagnosis and therapy have come from animal venoms. They often exhibit specificity and selectivity for tumor proteins have become an invaluable framework to develop future anti-cancer treatments [29]. Molecular-imaging techniques have integrated venom-based moieties into numerous applications for tumor visualization and/or delivery of therapeutic anti-tumor agents [29,30]. Labelling these therapeutic agents with potential optical, magnetic resonance, or nuclear medicine imaging moieties allows for validation of the therapeutic profile in vivo along with directly determining the bio-distribution of the material [31,32]. Considering its molecular structure, CTX-based platforms can potentially be harnessed for drug development. Many applications have used CTX-based strategies for developing novel therapeutic and diagnostic techniques for detecting glioma [33,34], as shown in Table 1.

Table 1. Summary of various CTX-conjugate compounds.

\begin{tabular}{ccc}
\hline CTX-Conjugate & Imaging Modality & References \\
\hline${ }^{131} \mathrm{I} /{ }^{125} \mathrm{I}-\mathrm{CTX}\left({ }^{131} \mathrm{I}-\mathrm{T} M 601\right)$ & SPECT Imaging & {$[10,35-38]$} \\
${ }^{131} \mathrm{I}-\mathrm{BmK}-\mathrm{CT}$ & SPECT imaging & {$[39]$} \\
Ag/Ali-PNPs-CTX-99m Tc & SPECT imaging & {$[40]$} \\
${ }^{131}$ I-HPAO-PEG-dendrimers-CTX & SPECT imaging & {$[41,42]$} \\
Cy5.5-CTX & Optical Imaging & {$[43]$} \\
Mono-labeled CTX-Cy5.5 & Optical Imaging & {$[18]$} \\
IRDye 800CW-CTX & Optical Imaging & {$[44]$} \\
Pdot-CTX & Optical Imaging & {$[45]$} \\
PEI-NaYF(4):Yb, Er/Ce-CTX & Optical Imaging & {$[46]$} \\
QD(Ag-In-S/ZnS)-CTX & Optical Imaging & {$[47]$} \\
ICG-CTX (BLZ100) & Optical Imaging & {$[48]$} \\
NP-AF647-(DNA or siRNA)-CTX & Optical Imaging & {$[49,50]$} \\
IONP-PEG-CTX & MRI & {$[51]$} \\
IONP-PEG-Chitosan-DNA-CTX & MRI & {$[52]$} \\
MFNP-SiNP-CTX & MR/Optical imaging & {$[53]$} \\
IONP-PEG-Chitosan-Cy5.5-CTX & MR/Optical imaging & {$[54]$} \\
IONP-PEG-CTX & MR/Optical imaging & {$[55,56]$} \\
NaGdF 4 -Ho ${ }^{3+}$-CTX & MR/Optical imaging & {$[57]$} \\
Gd-DTPA/BODIPY-dendrigraft poly-L-lysines-PEG-CTX & MR/Optical imaging & {$[58]$} \\
\hline
\end{tabular}

CTX: Chlorotoxin; Bmk-CT: Buthus martensii Karsch CTX like toxine; Ag/Ali-PNPs: Silver and alisertib polymeric nanoparticle; HPAO-PEG: 3-(4'-hydroxyphenyl)propionic acid-OSu-polyethylene glycol; PBdot: Polymer-blend dots conjugate; PEI-NaYF(4): Yb, Er/Ce: Polyethylenimine-coated hexagonal-phase NaYF(4):Yb, Er/Ce nanoparticles; QD: Quantum dots; ICG: Indocyanine green; NP: Nanoparticles; IONP: Iron oxide nanoparticles; MFNP-SiNP: Magnetite nanoparticle clusters in fluorescent silica nanoparticles; Magnetic resonance imaging (MRI); $\mathrm{NaGdF}_{4}-\mathrm{Ho}^{3}$ : Lanthanide-ion doped $\mathrm{NaGdF}_{4}$ nanoparticles; Gd-DTPA: Gadolinium- diethylenetriamine pentaacetate; BODIPY: Distyryl-substituted boradiazaindacene. 


\subsection{CTX-Based Nuclear Imaging}

CTX has been used with positron emission tomography (PET) and single photon emission computed tomography (SPECT), for the development of new oncology-related contrast agents. Further, CTX can allow for the generation of "theranostic" agents that combine imaging and therapeutic agents in the same molecule [59]. These imaging modalities are attractive techniques to study the biodistribution and pharmacokinetics of novel targeted therapies and provide specific information about tumor physiology [32,60]. Radioactive iodine $\left({ }^{125} \mathrm{I}\right.$ and $\left.{ }^{131} \mathrm{I}\right)$ attached to CTX was the first compound translated to the clinic. This compound was designed to inhibit tumor growth as a radiotherapy agent as well as assess tumor volume and anatomical location [36,37]. Studies using ${ }^{125}$ I-labelled CTX have revealed glioma binding sites, for which CTX has both high and low affinities and could aid in identifying cancerous cells in biopsies from human glioma patients. ${ }^{131}$ I-CTX preferentially accumulated in tumor tissues following intravenous injection into immuno-deficient mice bearing human gliomas [10,35]. Despite promising preclinical results, this compound with the commercial name ${ }^{131} \mathrm{I}-\mathrm{TM} 601$ did not kill glioma cells in vitro when given as a single agent. Moreover, the radiochemical was detected in the stomach, kidneys, and thyroid of these animals. ${ }^{125}$ I-CTX was rapidly cleared through the urinary system and from all tissues except the stomach and thyroid [54]. As a result of this study ${ }^{131}$ I-TM-601 was further developed as a targeting agent for delivering therapeutic payloads. This compound entered clinical trials in adult patients with advanced-stage malignant GBMs and melanomas, and was subsequently used to investigate recurrent GBM $[36,37,61]$. A phase I clinical trial reported that a single intracranial dose of ${ }^{131}$ I-TM-601 was well tolerated and cleared from the body between 24 and $48 \mathrm{~h}$ [37]. As determined by the preclinical studies, ${ }^{131} \mathrm{I}-\mathrm{TM}-601$ accumulated in the tumor periphery, while radiation doses in normal tissues and organs were not significant. Adverse effects were minimal and primarily related to the route of administration with no major toxicity or mortality due to ${ }^{131}$ I-TM-601 administration have been reported [37,38,42].

${ }^{131}$ I-labeled dendrimers conjugated to CTX has also been used as theranostic SPECT agents. This dendrimer-based platform sequentially conjugate polyethylene glycol (PEG), with CTX as a targeting agent and 3-(4'-hydroxyphenyl) propionic acid-OSu (HPAO), followed by ${ }^{131} \mathrm{I}$ radiolabeling. The binding specificity of this construct was demonstrated in vitro on a C6 cancer cell line and in vivo on an MMP2-overexpressing glioma mouse model [39]. CTX was also used as a targeting agent for other theranostic platforms designed for SPECT imaging. A novel CTX-based polymeric nanoparticle radiolabeled with ${ }^{99 \mathrm{~m}} \mathrm{Tc}$ that contained two cytotoxic agents, alisertib and silver nanoparticles, has been developed as a theranostic agent [40]. The targeting ability of this compound was tested on a U87MG glioblastoma cell line and in vivo in U87MG-tumor bearing mice. Another advanced approach utilized CTX-like peptide radiolabeled with ${ }^{131}$ I, a recombinant CTX-like toxin isolated from Buthus martensii Karsch (BmK) to inhibited glioma cells development and invasion [33-35]. Nevertheless, more detailed study of the safety and availability of these CTX-conjugates should take into account serum and albumin binding, binding to vessel walls, lymphocyte binding, and uptake by macrophages when used systemically. Although, the potential use of CTX for cancer theranostics is broad, only small number of compounds will reach the clinic. Therefore, more effort is needs in developing novel CTX-based theranostics for the diagnosis and treatment of gliomas.

\subsection{CTX-Based MRI/Optical Imaging}

CTX has been used as a target delivery of magnetic resonance imaging (MRI) contrast agents or nanoprobes (NP) to tumor tissues [51]. MRI contrast was used to determine the extent of the tumor and for defining its precise localization within the brain. Gadolinium (Gd(III)) is frequently chelated by small molecules such diethylenetriamine pentaacetate (DTPA) for routine MRI contrast [62]. Gd(III) chelates tend to be rapidly cleared from circulation and do not possess intrinsic targeting capabilities [38]. An attempt to improve the targeting of Gd-based contrast agents was the development of poly-L-lysine dendrigraft containing Gd(III) $[58,63]$. This construct was composed of a L-lysine dendritic macromolecule conjugated to CTX either with Gd chelates or 
distyryl-substituted boradiazaindacene (BODIPY) fluorophore. The addition of a targeting function to the contrast agent provided a better uptake and enhanced retention time in tumor cells without apparent toxicity [58]. Longer circulation times and greater retention at tumor sites was also achieved by using iron oxide nanoparticles (IONP) $[64,65]$. Typical IONPs are comprised of solid iron oxide cores (usually magnetite, $\mathrm{Fe}_{3} \mathrm{O}_{4}$, or its oxidized form maghemite, $\gamma$ - $\mathrm{Fe}_{2} \mathrm{O}_{3}$ ) with a biocompatible polymer coating [66]. Local interactions between iron and water protons accelerates proton dephasing to shorten transverse T2 relaxation times and enhance MRI contrast upon T2* imaging [67-69]. Likewise, fluorescent dyes can also be linked onto the surface of IONPs through the coated polymer allowing for multimodality investigation (i.e., MRI and optical imaging) of brain tumors [70].

CTX can be functionalized onto the surface of IONP pre-coated with PEG or a copolymer of PEG and chitosan $[53,55,56,71,72]$. IONPs have also been conjugated to CTX and Cy5.5 to create multimodal agents detectable using MRI and optical imaging [56]. Preferential targeting abilities of CTX-NP-Cy5.5 were determined via specific binding to glioma cells in vitro compared to NPs without CTX conjugation. In a follow-up study, IONPs were coated with PEG/chitosan and conjugated with CTX and Cy5.5. The CTX-Cy5.5 NP were efficiently internalized by tumors cells and inhibited invasion of C6 glioma cells compared to unconjugated IONPs $(\approx 45 \%)[43,71]$. This nontoxic compound proved to be permeable through the BBB allowing for a prolong detection by optical imaging and MRI of tumor cells in genetically engineered mice [51]. Real-time biological information to precisely detect small foci of cancer cells along with tumor margins could be achieved by optical imaging [51]. Nevertheless, this study had several weaknesses that made it difficult to translate to the clinic such as weak optical and MRI signals and poor photo-stability. Moreover, it was the only study we could find showing that Cy5.5-conjugated CTX-labelled glioma cells without affecting the BBB [43]. Disturbance in the BBB by tumors may depend on the tumor type and the stage of progression. CTX has been reported to cross the BBB and blood tumor barrier [33], diffusing deeply into the tumors, while other targeting agents, such as antibodies, were not able to cross the BBB [38,50].

Optical imaging detects light emitted from fluorophores attached to ligands that bind specific molecular targets. A suitable intraoperative CTX-based conjugated for pre-malignant lesions identification and improve visualization of tumor boundaries are near infrared (NIR) fluorescent moieties. NIR dyes are poorly absorbed by water or hemoglobin thereby limiting the amount of interference from auto-fluorescence and optimizes signal intensity [51]. One such application is the complex Cy5.5-CTX composed of CTX conjugated to Cy5.5 [31,47]. Cy5.5-CTX demonstrated specific binding toward tumor cells, transfer across the BBB, and enabled the detection of metastatic cancer foci comprised of a few hundred cells. CTX complex was modified by Akcan et al. [28], resulting in a mono-labeled peptide containing a single NIR fluorescent molecule without impacting the functionality or efficacy of CTX. Other NIR fluorophore molecules have been designed with the ability to paint tumors by using a CTX targeting strategy that included IRDye800CW or indocyanine green (ICG) CTX:800CW or BLZ-100. Specificity and functionality of the targeted agent, IRDye 800CW-CTX, were confirmed in cell-based assays and specifically targeted tumor tissue in ND2:SmoA1 mice, a transgenic model that spontaneously develops medulloblastoma tumors (Figure 1C) [44]. Surprisingly, blocking of IRDye $800 \mathrm{CW}-\mathrm{CTX}$ binding was observed at $4{ }^{\circ} \mathrm{C}$, a temperature at which internalization is slower, while at room temperature it was unsuccessfully blocked. ICG-CTX conjugated to BLZ-100 allowed for clear visualization of human glioma cells implanted in mouse brains, whereas normal tissue did not take up this agent [48]. In addition, BLZ-100 was translated into the clinic and it is currently undergoing evaluation in Phase I clinical trials in adult patients with glioma (NCT02234297). Furthermore, this probe has been clinically evaluated for adult skin cancer (NCT02097875), sarcoma (NCT024643320), and for pediatric patients with central nervous system tumors (NCT02462629) [73].

Other promising fluorescence-based imaging probes developed for tumors detection are quantum dots (QDs). QDs can provide images across large ranges of wavelengths and have high quantum yields [74]. Unlike organic dyes, which often suffer rapid photo-bleaching [75,76], QDs are composed of semiconducting metals (e.g., Cd, Zn, Se, In, P, and As) that are resistant to photo-bleaching [77]. 
Furthermore, the quantum properties of QDs are tunable and can provide excitation/emission wavelengths ranging from ultraviolet (UV) to NIR. The outer shell of the QD could be modified by organic layers including PEG polymers, phospholipids, and peptides [78], thus preventing nonspecific absorption of proteins to their surface, increase blood half-life, and reducing toxicity $[79,80]$. CTX conjugated with cadmium-free silver-indium-sulfide (Ag-In-S or AIS) chalcopyrite QDs was used in cellular imaging studies [47]. This CTX-conjugated QD-micelles exhibited specific internalization into U-87 brain tumor cells. Although QDs offer potentially valuable benefits in preclinical oncology, such as drug targeting and in vivo biomedical imaging, under certain conditions, they pose risks to human health and the environment, constituting a barrier for their translation to clinical use [81]. Semiconducting polymer dots have aroused extensive interests as a novel family of fluorescent probes for tumor targeting applications [54,61]. Unlike QDs, polymer-based dots were developed from biologically non-toxic materials, using deep-red photo-acceptors and visible-light photo-donors. Wu et al. [34] developed a polymer-blend dots conjugate (PBdot-CTX) that was capable of permeating through the BBB and specifically targets tumor tissue in the ND2:SmoA1 medulloblastoma mouse model. The PBdot-CTX conjugate characterized to have a mean size of $15 \mathrm{~nm}$; was resistant to photo-bleaching, 15 times brighter than QDs, and stable in serum for over $72 \mathrm{~h} \mathrm{[45].}$

Lastly, a new class of nanoparticles, upconverting nanoparticles (UNCP), has recently been reported as functionalized fluorescent imaging agents. UNCP absorb low energy NIR (930 nm) wavelengths of light and "upconvert" to emit in the red visible spectrum $(660 \mathrm{~nm})$. This allows deep tissue penetration of excitation light and minimizes auto-fluorescence. Thus, the resulting signal-to-noise ratios are exceptionally high. In addition, these nanoprobes are soluble in aqueous solutions, are extremely photo stable, and fluoresce over long periods of time [82,83]. Rare-earth UNCP of polyethylenimine coated hexagonal-phase $\mathrm{NaYF}_{4}: \mathrm{Yb}, \mathrm{Er} / \mathrm{Ce}$ nanorods were functionalized with CTX and were shown to targeted C6 glioma xenografted tumors in vivo without appreciable signs of toxicity [46]. Recently CTX was conjugated onto lanthanide-ion doped NaGdF4 nanoparticles have been exploited as a new generation of MRI/optical probes [57]. Targeting ability of CTX-NaGdF $: \mathrm{Ho}^{3+}$ NPs towards glioma cells was confirmed in vitro and in vivo using MRI and fluorescence imaging. Despite progress in recent years, experimental animal studies may never accurately predict the outcomes of human clinical trials. Moreover, CTX bioconjugates are unlikely to retain similar properties as those of CTX. Therefore, further study and development of novel CTX-modalities are likely to lead to more effective strategies for brain tumor control.

\subsection{US/Optoacoustic Imaging of Glioma: Current Progress and Expectations}

Optoacoustic imaging has been explored preclinically and is an area of particular interest. Acoustic emissions can result from the absorption of pulsed light energy, which occurs in accordance to the profile of endogenous tissue chromophores. The magnitude of acoustic emissions is proportional to the magnitude of optical energy deposited in tissue, which allows biological structures to be visualized with high optical contrast and acoustical resolution [84]. This modality is a high-resolution imaging tool used to assess binding efficiencies of appropriate contrast agents [85]. Commonly used acoustic imaging contrast agents are microbubbles (MBs) and nanobubbles (NBs) [86]. MBs were originally developed as diagnostic ultrasound contrast agents but have since been explored for targeted drug delivery by enhancing vascular permeability through cavitation that occurs when bubbles reside in ultrasound fields [87]. Modifications of bubble surfaces permit targeting of diseased tissues, reduced immunogenicity, and prolonged circulation lifetimes. Various bubble formulations are used for drug $[88,89]$ or gene delivery [90]. To the best of our knowledge, research on developing CTX-targeted MBs have not been reported. Potentially, photoacoustic and/or ultrasound imaging could be used in conjunction with CTX-targeted MBs or NBs and be a valuable theranostic tool for gliomas.

By combining transcranial focused ultrasound (FUS) with MB infusions can transiently disrupt the BBB with high spatial precision and improves delivery chemotherapies into brain tumors [91,92]. 
Several studies have demonstrated enhanced central nervous system (CNS)-blood permeability [93,94] and increased local drug concentrations [95-97] following FUS exposure. Furthermore, additional therapeutic biologics, such genes and antibodies, have also been successfully delivered to the brain using FUS [98]. The BBB opening is transient, allowing the time window during which maximal chemotherapy doses could be delivered to tumors. Repeated use of FUS may permit planned high dose chemotherapy for CNS disease with minimal systemic toxicity $[99,100]$. The development of dual imaging/therapeutic molecules based on a FUS-induced BBB opening and CTX-functionalized nanoparticles could be the next breakthrough as a theranostic agent in glioma treatment. CTX-modified doxorubicin (DOX)-loaded liposomes [101], covalently linked CTX to liposomes encapsulating small interfering RNAs [49,50], or antisense oligo-nucleotides [52,61] could potentially be utilized as combined agent in GBM treatment management.

\section{Conclusions}

Overall, multiple applications have utilized CTX as a targeting domain over the past decade. CTX exhibits several properties advocating its use as an ideal platform for developing novel methods for imaging and therapy of glioma: (i) CTX's compact structure enables its penetration across the BBB; (ii) it preferentially binds gliomas and other cancers arising from the neuroectoderm like melanoma, neuroblastoma, and medulloblastoma, without binding to normal tissue; (iii) CTX enables prolonged retention due to the ability to be internalized into tumor cells; (iv) several human trials have been conducted without reported toxicity or immunoreactivity; (v) convenient structure modification via a tyrosine residue to conjugate a variety of imaging or therapy agents without compromising its functionality; and (vi) demonstrated tumor binding capabilities via specific recognition of MMP-2, chloride channels, and Annexin-2 [16,38,43,55,70,71]. All these make CTX a novel and versatile theranostic compound that could be a key part of future glioma-targeted imaging and therapy.

Author Contributions: G.C. wrote the first draft of the manuscript performed corrections and submitted the manuscript; S.R.B. and J.A.F. edited the manuscript and brought in valuable corrections.

Funding: The APC of this work was partly funded by MDPI's Institutional Open Access Program (IOAP).

Acknowledgments: This work was supported by the Intramural Research Programs of the Clinical Center, the National Institute of Biomedical Imaging and Bioengineering at the National Institutes of Health. We would like to thank Dror Cohen for the Israeli scorpion Leiurus quinquestriatu picture at its natural habitat in the dead sea, Israel.

Conflicts of Interest: The authors declare no conflict of interest.

\section{References}

1. Thakkar, J.P.; Dolecek, T.A.; Horbinski, C.; Ostrom, Q.T.; Lightner, D.D.; Barnholtz-Sloan, J.S.; Villano, J.L. Epidemiologic and molecular prognostic review of glioblastoma. Cancer Epidemiol. Biomark. Prev. 2014, 23, 1985-1996. [CrossRef] [PubMed]

2. Ostrom, Q.T.; Gittleman, H.; Fulop, J.; Liu, M.; Blanda, R.; Kromer, C.; Wolinsky, Y.; Kruchko, C.; Barnholtz-Sloan, J.S. CBTRUS statistical report: Primary brain and central nervous system tumors diagnosed in the United States in 2008-2012. Neuro Oncol. 2015, 17, iv1-iv62. [CrossRef] [PubMed]

3. Ostrom, Q.T.; Gittleman, H.; Xu, J.; Kromer, C.; Wolinsky, Y.; Kruchko, C.; Barnholtz-Sloan, J.S. CBTRUS statistical report: Primary brain and other central nervous system tumors diagnosed in the United States in 2009-2013. Neuro Oncol. 2016, 18, v1-v75. [CrossRef] [PubMed]

4. Nabors, L.B.; Ammirati, M.; Bierman, P.J.; Brem, H.; Butowski, N.; Chamberlain, M.C.; DeAngelis, L.M.; Fenstermaker, R.a.; Friedman, A.; Gilbert, M.R.; Hesser, D.; et al. NCCN clinical practice guidelines in oncology: Central nervous system cancers. J. Natl. Compr. Cancer Netw. 2014, 15, 1331-1345. [CrossRef] [PubMed]

5. Wilson, T.A.; Karajannis, M.A.; Harter, D.H. Glioblastoma multiforme: State of the art and future therapeutics. Surg. Neurol. Int. 2014, 5. [CrossRef] 
6. Mukherjee, D.; Quinones-Hinojosa, A. Impact of Extent of Resection on Outcomes in Patients with High-Grade Gliomas; Hayat, M.A., Ed.; Springer: Dordrecht, The Netherlands, 2011; ISBN 978-94-007-0618-7.

7. Zhao, S.; Wu, J.; Wang, C.; Liu, H.; Dong, X.; Shi, C.; Shi, C.; Liu, Y.; Teng, L.; Han, D.; et al. Intraoperative fluorescence-guided resection of high-grade malignant gliomas using 5-Aminolevulinic scid-induced porphyrins: A dystematic review and meta-analysis of prospective studies. PLoS ONE 2013, 8, e63682. [CrossRef]

8. $\quad$ Phillips, H.S.; Kharbanda, S.; Chen, R.; Forrest, W.F.; Soriano, R.H.; Wu, T.D.; Misra, A.; Nigro, J.M.; Colman, H.; Soroceanu, L.; et al. Molecular subclasses of high-grade glioma predict prognosis, delineate a pattern of disease progression, and resemble stages in neurogenesis. Cancer Cell 2006, 9, 157-173. [CrossRef] [PubMed]

9. Vitucci, M.; Hayes, D.N.; Miller, C.R. Gene expression profiling of gliomas: Merging genomic and histopathological classification for personalised therapy. Br. J. Cancer 2011, 104, 545-553. [CrossRef] [PubMed]

10. Soroceanu, L.; Gillespie, Y.; Khazaeli, M.B.; Sontheimer, H. Use of chlorotoxin for targeting of primary brain tumors. Cancer Res. 1998, 58, 4871-4879. [PubMed]

11. Olsen, M.L.; Schade, S.; Lyons, S.A.; Amaral, M.D.; Sontheimer, H. Expression of voltage-gated chloride channels in human glioma cells. J. Neurosci. 2003, 23, 5572-5582. [CrossRef] [PubMed]

12. McFerrin, M.B.; Sontheimer, H. A role for ion channels in glioma cell invasion. Neuron Glia Biol. 2006, 2, 39-49. [CrossRef] [PubMed]

13. Qin, C.; He, B.; Dai, W.; Lin, Z.; Zhang, H.; Wang, X.; Wang, J.; Zhang, X.; Wang, G.; Yin, L.; et al. The impact of a chlorotoxin-modified liposome system on receptor MMP-2 and the receptor-associated protein $\mathrm{ClC}-3$. Biomaterials 2014, 35, 5908-5920. [CrossRef] [PubMed]

14. Deshane, J.; Garner, C.C.; Sontheimer, H. Chlorotoxin inhibits glioma cell invasion via matrix metalloproteinase-2. J. Biol. Chem. 2003, 278, 4135-4144. [CrossRef] [PubMed]

15. Cohen-Inbar, O.; Zaaroor, M. Glioblastoma multiforme targeted therapy: The Chlorotoxin story. J. Clin. Neurosci. 2016, 33, 52-58. [CrossRef] [PubMed]

16. Ojeda, P.G.; Wang, C.K.; Craik, D.J. Chlorotoxin: Structure, activity, and potential uses in cancer therapy. Biopolymers 2016, 106, 25-36. [CrossRef] [PubMed]

17. Lippens, G.; Najib, J.; Tartar, A.; Lippens, G.; Wodak, S.J. NMR sequential assignments and solution structure of chlorotoxin, a small scorpion toxin that blocks chloride channels. Biochemistry 1995, 34, 13-21. [CrossRef] [PubMed]

18. Akcan, M.; Stroud, M.R.; Hansen, S.J.; Clark, R.J.; Daly, N.L.; Craik, D.J.; Olson, J.M. Chemical re-engineering of chlorotoxin improves bioconjugation properties for tumor imaging and targeted therapy. J. Med. Chem. 2011, 54, 782-787. [CrossRef] [PubMed]

19. DeBin, J.A.; Maggio, J.E.; Strichartz, G.R. Purification and characterization of chlorotoxin, a chloride channel ligand from the venom of the scorpion. Am. J. Physiol. 1993, 264, C361-C369. [CrossRef] [PubMed]

20. Bontems, F.; Gilquin, B.; Roumestand, C.; Ménez, A.; Toma, F. Analysis of side-chain organization on a refined model of charybdotoxin: Structural and functional implications. Biochemistry 1992, 31, 7756-7764. [CrossRef] [PubMed]

21. Ullrich, N.; Bordey, A.; Gillespie, G.Y.; Sontheimer, H. Expression of voltage-activated chloride currents in acute slices of human gliomas. Neuroscience 1998, 83, 1161-1173. [CrossRef]

22. Ullrich, N.; Sontheimer, H. Cell cycle-dependent expression of a glioma-specific chloride current: Proposed link to cytoskeletal changes. Am. J. Physiol. 1997, 273, C1290-C1297. [CrossRef] [PubMed]

23. Turner, K.L.; Sontheimer, ${\mathrm{H} . \mathrm{Cl}^{-}}^{-}$and $\mathrm{K}^{+}$channels and their role in primary brain tumour biology. Philos. Trans. R. Soc. B Biol. Sci. 2014, 369, 20130095. [CrossRef] [PubMed]

24. Maertens, C.; Wei, L.; Tytgat, J.; Droogmans, G.; Nilius, B. Chlorotoxin does not inhibit volume-regulated, calcium-activated and cyclic AMP-activated chloride channels. Br. J. Pharmacol. 2000, 129, 791-801. [CrossRef] [PubMed]

25. Lokman, N.A.; Ween, M.P.; Oehler, M.K.; Ricciardelli, C. The role of annexin A2 in tumorigenesis and cancer progression. Cancer Microenviron. 2011, 4, 199-208. [CrossRef] [PubMed]

26. Mamelak, A.N. Targeted antitumor therapy with the scorpion venom chlorotoxin. Drugs Future 2011, 36, 615. [CrossRef] 
27. Kesavan, K.; Ratliff, J.; Johnson, E.W.; Dahlberg, W.; Asara, J.M.; Misra, P.; Frangioni, J.V.; Jacoby, D.B. Annexin A2 is a molecular target for TM601, a peptide with tumor-targeting and anti-angiogenic effects. J. Biol. Chem. 2010, 285, 4366-4374. [CrossRef] [PubMed]

28. Tatenhorst, L.; Rescher, U.; Gerke, V.; Paulus, W. Knockdown of annexin 2 decreases migration of human glioma cells in vitro. Neuropathol. Appl. Neurobiol. 2006, 32, 271-277. [CrossRef] [PubMed]

29. Ma, R.; Mahadevappa, R.; Kwok, H.F. Venom-based peptide therapy: Insights into anti-cancer mechanism. Oncotarget 2017, 8, 100908-100930. [CrossRef] [PubMed]

30. Ortiz, E.; Gurrola, G.B.; Schwartz, E.F.; Possani, L.D. Scorpion venom components as potential candidates for drug development. Toxicon 2015, 93, 125-135. [CrossRef] [PubMed]

31. Al-Lazikani, B.; Banerji, U.; Workman, P. Combinatorial drug therapy for cancer in the post-genomic era. Nat. Biotechnol. 2012, 30, 679-692. [CrossRef] [PubMed]

32. Puttick, S.; Bell, C.; Dowson, N.; Rose, S.; Fay, M. PET, MRI, and simultaneous PET/MRI in the development of diagnostic and therapeutic strategies for glioma. Drug Discov. Today 2015, 20, 306-317. [CrossRef] [PubMed]

33. Dardevet, L.; Rani, D.; El Aziz, T.A.; Bazin, I.; Sabatier, J.M.; Fadl, M.; Brambilla, E.; De Waard, M. Chlorotoxin: A helpful natural scorpion peptide to diagnose glioma and fight tumor invasion. Toxins 2015, 7, 1079-1101. [CrossRef] [PubMed]

34. Fu, Y.; An, N.; Li, K.; Zheng, Y.; Liang, A. Chlorotoxin-conjugated nanoparticles as potential glioma-targeted drugs. J. Neurooncol. 2012, 107, 457-462. [CrossRef] [PubMed]

35. Shen, S.; Khazaeli, M.B.; Gillespie, G.Y.; Alvarez, V.L. Radiation dosimetry of 131I-chlorotoxin for targeted radiotherapy in glioma-bearing mice. J. Neurooncol. 2005, 71, 113-119. [CrossRef] [PubMed]

36. Hockaday, D.C.; Shen, S.; Fiveash, J.; Raubitschek, A.; Colcher, D.; Liu, A.; Alvarez, V.; Mamelak, A.N. Imaging glioma extent with 131I-TM-601. J. Nucl. Med. 2005, 46, 580-586. [PubMed]

37. Mamelak, A.N.; Rosenfeld, S.; Bucholz, R.; Raubitschek, A.; Nabors, L.B.; Fiveash, J.B.; Shen, S.; Khazaeli, M.B.; Colcher, D.; Liu, A.; et al. Phase I single-dose study of intracavitary-administered iodine-131-TM-601 in adults with recurrent high-grade glioma. J. Clin. Oncol. 2006, 24, 3644-3650. [CrossRef] [PubMed]

38. Mamelak, A.N.; Jacoby, D.B. Targeted delivery of antitumoral therapy to glioma and other malignancies with synthetic chlorotoxin (TM-601). Expert Opin. Drug Deliv. 2007, 4, 175-186. [CrossRef] [PubMed]

39. Zhao, L.; Zhu, J.; Cheng, Y.; Xiong, Z.; Tang, Y.; Guo, L.; Shi, X.; Zhao, J. Chlorotoxin-conjugated multifunctional dendrimers labeled with radionuclide 131I for single photon emission computed tomography imaging and radiotherapy of gliomas. ACS Appl. Mater. Interfaces 2015, 7, 19798-19808. [CrossRef] [PubMed]

40. Locatelli, E.; Naddaka, M.; Uboldi, C.; Loudos, G.; Fragogeorgi, E.; Molinari, V.; Pucci, A.; Tsotakos, T.; Psimadas, D.; Ponti, J.; et al. Targeted delivery of silver nanoparticles and alisertib: In vitro and in vivo synergistic effect against glioblastoma. Nanomedicine 2014, 9, 839-849. [CrossRef] [PubMed]

41. Sun, N.; Zhao, L.; Qiao, W.; Xing, Y.; Zhao, J. BmK CT and 125I-BmK CT suppress the invasion of glioma cells in vitro via matrix metalloproteinase-2. Mol. Med. Rep. 2017, 15, 2703-2708. [CrossRef] [PubMed]

42. Wu, X.S.; Jian, X.C.; Yin, B.; He, Z.J. Development of the research on the application of chlorotoxin in imaging diagnostics and targeted therapies for tumors. Chin. J. Cancer 2010, 29, 626-630. [CrossRef] [PubMed]

43. Veiseh, M.; Gabikian, P.; Bahrami, S.B.; Veiseh, O.; Zhang, M.; Hackman, R.C.; Ravanpay, A.C.; Stroud, M.R.; Kusuma, Y.; Hansen, S.J.; et al. Tumor paint: A chlorotoxin:Cy5.5 bioconjugate for intraoperative visualization of cancer foci. Cancer Res. 2007, 67, 6882-6888. [CrossRef] [PubMed]

44. Kovar, J.L.; Curtis, E.; Othman, S.F.; Simpson, M.A.; Olive, D.M. Characterization of IRDye 800CW chlorotoxin as a targeting agent for brain tumors. Anal. Biochem. 2013, 440, 212-219. [CrossRef] [PubMed]

45. Wu, C.; Hansen, S.J.; Hou, Q.; Yu, J.; Zeigler, M.; Jin, Y.; Burnham, D.R.; McNeill, J.D.; Olson, J.M.; Chiu, D.T. Design of highly emissive polymer dot bioconjugates for in vivo tumor targeting. Angew. Chem. 2011, 50, 3430-3434. [CrossRef] [PubMed]

46. Yu, X.F.; Sun, Z.; Li, M.; Xiang, Y.; Wang, Q.Q.; Tang, F.; Wu, Y.; Cao, Z.; Li, W. Neurotoxin-conjugated upconversion nanoprobes for direct visualization of tumors under near-infrared irradiation. Biomaterials 2010, 31, 8724-8731. [CrossRef] [PubMed]

47. Chen, S.; Ahmadiantehrani, M.; Publicover, N.G.; Hunter, K.W.J.; Zhu, X. Thermal decomposition based synthesis of Ag-In-S/ZnS quantum dots and their chlorotoxin-modified micelles for brain tumor cell targeting. RSC Adv. 2015, 74, 60612-60620. [CrossRef] [PubMed] 
48. Butte, P.V.; Mamelak, A.; Parrish-Novak, J.; Drazin, D.; Shweikeh, F.; Gangalum, P.R.; Chesnokova, A.; Ljubimova, J.Y.; Black, K. Near-infrared imaging of brain tumors using the tumor paint BLZ-100 to achieve near-complete resection of brain tumors. Neurosurg. Focus 2014, 36, E1. [CrossRef] [PubMed]

49. Veiseh, O.; Kievit, F.M.; Fang, C.; Mu, N.; Jana, S.; Leung, M.C.; Mok, H.; Ellenbogen, R.G.; Park, J.O.; Zhang, M. Chlorotoxin bound magnetic nanovector tailored for cancer cell targeting, imaging, and siRNA delivery. Biomaterials 2010, 31, 8032-8042. [CrossRef] [PubMed]

50. Veiseh, O.; Kievit, F.M.; Gunn, J.W.; Ratner, B.D.; Zhang, M. A ligand-mediated nanovector for targeted gene delivery and transfection in cancer cells. Biomaterials 2009, 30, 649-657. [CrossRef] [PubMed]

51. Sun, C.; Fang, C.; Stephen, Z.; Veiseh, O.; Hansen, S.; Lee, D.; Ellenbogen, R.G.; Olson, J.; Zhang, M. Tumor-targeted drug delivery and MRI contrast enhancement by chlorotoxin-conjugated iron oxide nanoparticles. Nanomedicine 2008, 3, 495-505. [CrossRef] [PubMed]

52. Kievit, F.M.; Veiseh, O.; Fang, C.; Bhattarai, N.; Lee, D.; Ellenbogen, R.G.; Zhang, M. Chlorotoxin labeled magnetic nanovectors for targeted gene delivery to glioma. ACS Nano 2010, 4, 4587-4594. [CrossRef] [PubMed]

53. Wan, J.; Meng, X.; Liu, E.; Chen, K. Incorporation of magnetite nanoparticle clusters in fluorescent silica nanoparticles for high-performance brain tumor delineation. Nanotechnology 2010, 21, 235104. [CrossRef] [PubMed]

54. Lee, M.J.E.; Veiseh, O.; Bhattarai, N.; Sun, C.; Hansen, S.J.; Ditzler, S.; Knoblaugh, S.; Lee, D.; Ellenbogen, R.; Zhang, M.; et al. Rapid pharmacokinetic and biodistribution studies using cholorotoxin-conjugated iron oxide nanoparticles: A novel non-radioactive method. PLoS ONE 2010, 5, e9536. [CrossRef]

55. Sun, C.; Veiseh, O.; Gunn, J.; Fang, C.; Hansen, S.; Lee, D.; Sze, R.; Ellenbogen, R.G.; Olson, J.; Zhang, M. In vivo MRI detection of gliomas by chlorotoxin-conjugated superparamagnetic nanoprobes. Small 2008, 4, 372-379. [CrossRef] [PubMed]

56. Veiseh, O.; Sun, C.; Gunn, J.; Kohler, N.; Gabikian, P.; Lee, D.; Bhattarai, N.; Ellenbogen, R.; Sze, R.; Hallahan, A.; et al. Optical and MRI multifunctional nanoprobe for targeting gliomas. Nano Lett. 2005, 5, 1003-1008. [CrossRef] [PubMed]

57. Deng, Y.; Wang, H.; Gu, W.; Li, S.; Xiao, N.; Shao, C.; Xu, Q.; Ye, L. Ho ${ }^{3+}$ doped NaGdF4 nanoparticles as MRI/optical probes for brain glioma imaging. J. Mater. Chem. B 2014, 2, 1521-1529. [CrossRef]

58. Huang, R.; Han, L.; Li, J.; Liu, S.; Shao, K.; Kuang, Y.; Hu, X.; Wang, X.; Lei, H.; Jiang, C. Chlorotoxin-modified macromolecular contrast agent for MRI tumor diagnosis. Biomaterials 2011, 32, 5177-5186. [CrossRef] [PubMed]

59. Kelkar, S.S.; Reineke, T.M. Theranostics: Combining imaging and therapy. Bioconjug. Chem. 2011, 22, 1879-1903. [CrossRef] [PubMed]

60. Rahmim, A.; Zaidi, H. PET versus SPECT: Strengths, limitations and challenges. Nucl. Med. Commun. 2008, 29, 193-207. [CrossRef] [PubMed]

61. Cheng, Y.; Zhao, J.; Qiao, W.; Chen, K. Recent advances in diagnosis and treatment of gliomas using chlorotoxin-based bioconjugates. Am. J. Nucl. Med. Mol. Imaging 2014, 4, 385-405. [PubMed]

62. Lebduková, P.; Sour, A.; Helm, L.; Tóth, É.; Kotek, J.; Luke, I.; Merbach, A.E. Phosphinic derivative of DTPA conjugated to a G5 PAMAM dendrimer: An17O and1H relaxation study of its Gd(III) complex. Dalt. Trans. 2006, 3399-3406. [CrossRef] [PubMed]

63. Park, J.; Gu, L.; Von Maltzahn, G.; Ruoslahti, E.; Bhatia, S.N.; Sailor, M.J. Biodegradable luminescent porous silicon nanoparticles for in vivo applications. Nat. Mater. 2009, 8, 331-336. [CrossRef] [PubMed]

64. Bourrinet, P.; Bengele, H.H.; Bonnemain, B.; Dencausse, A.; Idee, J.M.; Jacobs, P.M.; Lewis, J.M. Preclinical safety and pharmacokinetic profile of ferumoxtran-10, an ultrasmall superparamagnetic iron oxide magnetic resonance contrast agent. Invest. Radiol. 2006, 41, 313-324. [CrossRef] [PubMed]

65. Varallyay, P.; Nesbit, G.; Muldoon, L.L.; Nixon, R.R.; Delashaw, J.; Cohen, J.I.; Petrillo, A.; Rink, D.; Neuwelt, E.A. Comparison of two superparamagnetic viral-sized iron oxide particles ferumoxides and ferumoxtran-10 with a gadolinium chelate in imaging intracranial tumors. Am. J. Neuroradiol. 2002, 23, 509-510.

66. Momtazi, L.; Bagherifam, S.; Singh, G.; Hofgaard, A.; Hakkarainen, M.; Glomm, W.R.; Roos, N.; Maelandsmo, G.M.; Griffiths, G.; Nystrom, B.; et al. Synthesis, characterization, and cellular uptake of magnetic nanocarriers for cancer drug delivery. J. Colloid Interface Sci. 2014, 1, 76-85. [CrossRef] [PubMed] 
67. Liu, H.; Zhang, J.; Chen, X.; Du, X.S.; Zhang, J.L.; Liu, G.; Zhang, W.G. Application of iron oxide nanoparticles in glioma imaging and therapy: From bench to bedside. Nanoscale 2016, 8, 7808-7826. [CrossRef] [PubMed]

68. Yigit, M.V.; Moore, A.; Medarova, Z. Magnetic nanoparticles for cancer diagnosis and therapy. Pharm. Res. 2012, 29, 1180-1188. [CrossRef] [PubMed]

69. Choi, J.S.; Jun, Y.W.; Yeon, S.I.; Kim, H.C.; Shin, J.S.; Cheon, J. Biocompatible heterostructured nanoparticles for multimodal biological detection. J. Am. Chem. Soc. 2006, 128, 15982-15983. [CrossRef] [PubMed]

70. Zhao, L.; Shi, X.; Zhao, J. Chlorotoxin-conjugated nanoparticles for targeted imaging and therapy of glioma. Curr. Top. Med. Chem. 2015, 15, 1196-1208. [CrossRef] [PubMed]

71. Veiseh, O.; Gunn, J.W.; Kievit, F.M.; Sun, C.; Fang, C.; Lee, J.S.H.; Zhang, M. Inhibition of tumor-cell invasion with chlorotoxin-bound superparamagnetic nanoparticles. Small 2009, 5, 256-264. [CrossRef] [PubMed]

72. Veiseh, O.; Sun, C.; Fang, C.; Bhattarai, N.; Gunn, J.; Kievit, F.; Du, K.; Pullar, B.; Lee, D.; Ellenbogen, R.G.; et al. Specific targeting of brain tumors with an optical/magnetic resonance imaging nanoprobe across the blood-brain barrier. Cancer Res. 2009, 69, 6200-6207. [CrossRef] [PubMed]

73. Staderini, M.; Megia-Fernandez, A.; Dhaliwal, K.; Bradley, M. Peptides for optical medical imaging and steps towards therapy. Bioorg. Med. Chem. 2018, 26, 2816-2826. [CrossRef] [PubMed]

74. Alivisatos, A.P. Semiconductor clusters, nanocrystals, and quantum dots. Science 1996, $271,933-937$. [CrossRef]

75. Xing, Y.; Zhao, J.; Conti, P.S.; Chen, K. Radiolabeled nanoparticles for multimodality tumor imaging. Theranostics 2014, 4, 290-306. [CrossRef] [PubMed]

76. Iyer, G.; Michalet, X.; Chang, Y.P.; Pinaud, F.F.; Matyas, S.E.; Payne, G.; Weiss, S. High affinity scFv-hapten pair as a tool for quantum dot labeling and tracking of single proteins in live cells. Nano Lett. 2008, 8, 4618-4623. [CrossRef] [PubMed]

77. Bruchez, M.; Moronne, M.; Gin, P.; Weiss, S.; Alivisatos, A.P. Semiconductor nanocrystals as fluorescent biological labels. Science 1998, 281, 2013-2016. [CrossRef] [PubMed]

78. Wang, Y.; Chen, L. Quantum dots, lighting up the research and development of nanomedicine. Nanomed. Nanotechnol. Biol. Med. 2011, 7, 385-402. [CrossRef] [PubMed]

79. Hauck, T.S.; Anderson, R.E.; Fischer, H.C.; Newbigging, S.; Chan, W.C.W. In vivo quantum-dot toxicity assessment. Small 2010, 6, 138-144. [CrossRef] [PubMed]

80. Jokerst, J.V.; Lobovkina, T.; Zare, R.N.; Gambhir, S.S. Nanoparticle PEGylation for imaging and therapy. Nanomedicine 2011, 6, 715-728. [CrossRef] [PubMed]

81. Hardman, R. A toxicologic review of quantum dots: Toxicity depends on physicochemical and environmental factors. Environ. Health Perspect. 2006, 114, 165-172. [CrossRef] [PubMed]

82. Mader, H.S.; Kele, P.; Saleh, S.M.; Wolfbeis, O.S. Upconverting luminescent nanoparticles for use in bioconjugation and bioimaging. Curr. Opin. Chem. Biol. 2010, 14, 582-596. [CrossRef] [PubMed]

83. Stroud, M.R.; Hansen, S.J.; Olson, J.M. In vivo bio-imaging using chlorotoxin-based conjugates. Curr. Pharm. Des. 2011, 17, 4362-4371. [CrossRef] [PubMed]

84. Xu, M.; Wang, L.V. Photoacoustic imaging in biomedicine. Rev. Sci. Instrum. 2006, 77, 041101. [CrossRef]

85. Bost, W.; Fournelle, M. Molecular imaging of glioblastoma cells using functionalized nanorods and a high resolution optoacoustic microscope. IEEE Int. Ultrason. Symp. IUS 2013, 120-123. [CrossRef]

86. Kim, C.; Qin, R.; Xu, J.S.; Wang, L.V.; Xu, R. Multifunctional microbubbles and nanobubbles for photoacoustic and ultrasound imaging. J. Biomed. Opt. 2010, 15, 10510. [CrossRef] [PubMed]

87. Goertz, D.E. An overview of the influence of therapeutic ultrasound exposures on the vasculature: High intensity ultrasound and microbubble-mediated bioeffects. Int. J. Hyperth. 2015, 31, 134-144. [CrossRef] [PubMed]

88. Bull, J.L. The application of microbubbles for targeted drug delivery. Expert Opin. Drug Deliv. 2007, 4, 475-493. [CrossRef] [PubMed]

89. Lum, A.F.H.; Borden, M.A.; Dayton, P.A.; Kruse, D.E.; Simon, S.I.; Ferrara, K.W. Ultrasound radiation force enables targeted deposition of model drug carriers loaded on microbubbles. J. Control. Release 2006, 111, 128-134. [CrossRef] [PubMed]

90. Chen, S.; Shohet, R.V.; Bekeredjian, R.; Frenkel, P.; Grayburn, P.A. Optimization of ultrasound parameters for cardiac gene delivery of adenoviral or plasmid deoxyribonucleic acid by ultrasound-targeted microbubble destruction. J. Am. Coll. Cardiol. 2003, 42, 301-308. [CrossRef] 
91. Sheikov, N.; McDannold, N.; Sharma, S.; Hynynen, K. Effect of focused ultrasound applied with an ultrasound contrast agent on the tight junctional integrity of the brain microvascular endothelium. Ultrasound Med. Biol. 2008, 34, 1093-1104. [CrossRef] [PubMed]

92. Hynynen, K.; McDannold, N.; Vykhodtseva, N.; Jolesz, F.A. Noninvasive MR imaging-guided focal opening of the blood-brain barrier in rabbits. Radiology 2001, 220, 640-646. [CrossRef] [PubMed]

93. Kovacs, Z.I.; Burks, S.R.; Frank, J.A. Focused ultrasound with microbubbles induces sterile inflammatory response proportional to the blood brain barrier opening: Attention to experimental conditions. Theranostics 2018, 8, 2245-2248. [CrossRef] [PubMed]

94. Kovacs, Z.I.; Kim, S.; Jikaria, N.; Qureshi, F.; Milo, B.; Lewis, B.K.; Bresler, M.; Burks, S.R.; Frank, J.A. Disrupting the blood-brain barrier by focused ultrasound induces sterile inflammation. Proc. Natl. Acad. Sci. USA 2017, 114, E75-E84. [CrossRef] [PubMed]

95. Yang, F.Y.; Teng, M.C.; Lu, M.; Liang, H.F.; Lee, Y.R.; Yen, C.C.; Liang, M.L.; Wong, T.T. Treating glioblastoma multiforme with selective high-dose liposomal doxorubicin chemotherapy induced by repeated focused ultrasound. Int. J. Nanomed. 2012, 7, 965-974. [CrossRef] [PubMed]

96. Ting, C.Y.; Fan, C.H.; Liu, H.L.; Huang, C.Y.; Hsieh, H.Y.; Yen, T.C.; Wei, K.C.; Yeh, C.K. Concurrent blood-brain barrier opening and local drug delivery using drug-carrying microbubbles and focused ultrasound for brain glioma treatment. Biomaterials 2012, 33, 704-712. [CrossRef] [PubMed]

97. Yang, F.Y.; Wang, H.E.; Lin, G.L.; Lin, H.H.; Wong, T.T. Evaluation of the increase in permeability of the blood-brain barrier during tumor progression after pulsed focused ultrasound. Int. J. Nanomed. 2012, 7, 723-730. [CrossRef] [PubMed]

98. Vykhodtseva, N.; McDannold, N.; Hynynen, K. Progress and problems in the application of focused ultrasound for blood-brain barrier disruption. Ultrasonics 2008, 48, 279-296. [CrossRef] [PubMed]

99. Yang, F.-Y.; Chen, C.-C.; Kao, Y.-H.; Chen, C.-L.; Ko, C.-E.; Horng, S.-C.; Chen, R.-C. Evaluation of dose distribution of molecular delivery after blood-brain barrier disruption by focused ultrasound with treatment planning. Ultrasound Med. Biol. 2013, 39, 620-627. [CrossRef] [PubMed]

100. Yang, F.Y.; Ko, C.E.; Huang, S.Y.; Chung, I.F.; Chen, G.S. Pharmacokinetic changes induced by focused ultrasound in glioma-bearing rats as measured by dynamic contrast-enhanced MRI. PLoS ONE 2014, 9, e92910. [CrossRef] [PubMed]

101. Xiang, Y.; Liang, L.; Wang, X.; Wang, J.; Zhang, X.; Zhang, Q. Chloride channel-mediated brain glioma targeting of chlorotoxin-modified doxorubicine-loaded liposomes. J. Control. Release 2011, 152, 402-410. [CrossRef] [PubMed] 